\title{
Accumulation of arsenic during the growing period of rainbow trout (Oncorhynchus mykiss)
}

\author{
Olga Čelechovská1, Veronika Harkabusová1, Blanka Macharáčková1, Eva Vitoulová2, \\ Alena Lavičková ${ }^{1}$ \\ ${ }^{1}$ Department of Biochemistry, Chemistry and Biophysics, Faculty of Veterinary and Pharmaceutical Sciences, \\ University of Veterinary and Pharmaceutical Sciences, Brno, Czech Republic \\ ${ }^{2}$ Institute of Food Science and Biotechnology, Faculty of Chemistry, Brno University of Technology, \\ Czech Republic
}

Received July 30, 2010

Accepted October 26, 2010

\begin{abstract}
Rainbow trout (Oncorhynchus mykiss) was monitored for the duration of one year, from 2 to 14 months of age $(n=120)$. The study was performed on a farm with through-running water from the basin of water processing plant in the years 2007 and 2008. During the first months of fish life, we analyzed homogenized samples $(n=12)$ of rainbow trout bodies. From the $8^{\text {th }}$ month the samples of twelve rainbow trouts were analysed. The total contents of arsenic and arsenobetaine were quantified in muscle, liver, spleen and bile separately. The total arsenic was determined by hydride technique AAS and arsenobetaine by high performance liquid chromatography combined with detection using atomic fluorescence spectrometry. The concentration of arsenic in homogenized body samples grew $(P<0.01)$ during the first months of life, from the $6^{\text {th }}$ month of rearing no significant difference was found. The concentration of arsenobetaine in homogenized bodies was low during the first months and from the $6^{\text {th }}$ month the concentration stayed on invariable level and amounted to $46 \pm 6 \%$ of total arsenic. The highest concentrations of arsenic and arsenobetaine in tissues ranked in the order muscle, liver, spleen and bile. In summer months the total arsenic in muscle was bonded in the form of arsenobetaine, in winter months the content of arsenobetaine dropped to $50 \%$ of total arsenic. The content of arsenic in liver samples remained the same during the entire monitoring, however, the ratio of arsenobetaine content altered. In summer months it reached the maximum $27 \%$, in winter months it dropped to $7 \%$ of arsenic. The concentration of arsenic in spleen and bile decreased in winter months, arsenobetaine corresponded to the value assessed in liver. This study proved the effect of the small content of arsenic in feedstuff on accumulation of total arsenic and arsenobetaine in the tissue of rainbow trout during the growing period and season.
\end{abstract}

Arsenobetaine, tissue, atomic absorption spectrometry, hydride generation, atomic fluorescence spectrometry

Arsenic compounds enter the environment naturally by volcanic eruptions, forest fires and weather impacts such as erosion. The most serious anthropogenic sources of arsenic (including industrial emissions) are the ore mining and processing industry, thermal power plants, agriculture (application of insecticides, herbicides, algicides) and the wood-working industry (chemical preservation of wood) (Tamaki and Frankenberger 1992). Arsenic exists in a wide variety of chemical forms and oxidation states, which influences its bioavailability and toxicity. In recent years a number of publications have appeared dealing with the arsenic content in marine organisms (Agusa et al. 2008; Grotti et al. 2010; Francesconi 2010) and freshwater organisms (Celechovská et al. 2005; Ciardullo et al. 2010). More than 50 arsenic compounds were detected in marine organisms. Arsenobetaine (AsB), which is stable, metabolically inactive and non-toxic, predominates over all the arsenic species in edible parts of fish (Sloth et al. 2005). Inorganically bonded arsenic, although it is not the main component of total arsenic content in fish and crustaceans, represents a potential risk of toxicity. Out of the total arsenic content in 
samples of marine fish and crustaceans up to $44 \%$ was inorganically bonded. The ratio of individual components varies with fish species and environment - inorganic component is lower in freshwater fish (up to $27 \%$ ). A number of studies have been dealing with the shortperiod influence of arsenic compounds on a rainbow trout organism (McGeachy and Dix on 1989 and 1992; Rankin and Dix on 1994), lake whitefish Coregonus clupeaformis L. (Pedlar and Klaverkamp 2002; Pedlar et al. 2002ab) and common carp Cyprinus carpio L. (Ventura-Lima et al. 2009).

The aim of this study was to monitor the accumulation of arsenic in tissues of rainbow trout (Oncorhynchus mykiss) during intensive rearing, to monitor the content of organically bonded arsenic and to compare the total content of arsenic with the content of organically bonded arsenic.

\section{Materials and Methods}

The accumulation of arsenic in tissues of rainbow trout (Oncorhynchus mykiss) was monitored at an intensive rearing on the farm Kružberk. The rainbow trout were kept in tanks first with a volume of $0.2 \mathrm{~m}^{3}$, and later with volume of 1 and $5 \mathrm{~m}^{3}$ with through-running water from the reservoir of the water processing plant Kružberk (Moravice river, North Moravia, Czech Republic, 4949’23.94’N, 17³9’45.977’'E). Feeds containing fishmeal were the main nourishment. Throughout the first year of the growing period the fish were fed Bio-Optimal Start $1.1 \mathrm{~mm}$ (BioMar A/S, Denmark), after the first year they got additional feed - Aqualife R90 $4.5 \mathrm{~mm}$ (BioMar A/S, Denmark). Feed conversion ratio amounted to $1.1 \mathrm{~kg}$ of feed per $1 \mathrm{~kg}$ of fish weight gain. Temperature conditions of rearing and the increase in weight during trout growing period are stated in Table 1.

The rainbow trout were hatched in October 2007.

Table 1. Water temperature at particular stages of rainbow trout (Oncorhynchus mykiss) growing period and dates of sampling

\begin{tabular}{ccc}
\hline Months & $\mathrm{T}\left({ }^{\circ} \mathrm{C}\right)$ & Sampling \\
\hline $0-2$ & $5-9$ & $2007-12-03$ \\
$3-5$ & $2-4$ & $2008-01-30$ \\
& & $2008-04-06$ \\
$6-8$ & $5-12$ & $2008-06-03$ \\
& & $2008-07-29$ \\
$9-11$ & $12-14$ & $2008-09-25$ \\
$12-14$ & $5-8$ & $2008-11-01$ \\
& & $2008-12-18$ \\
\hline
\end{tabular}

technique with electrothermal atomization in iridium coated graphite tube preheated to $300{ }^{\circ} \mathrm{C}$ (Hydrae 60 , Analytik Jena AG, Germany). Prior to the determination of total arsenic, samples were mineralized with nitric acid and hydrogen peroxide in a microwave-heated laboratory autoclave (ETHOS SEL, Milestone, Italy). Then, after evaporating and adding magnesium nitrate, the mineralized samples were burnt to ashes in muffle furnace at $450{ }^{\circ} \mathrm{C}$. Subsequently, the ashes were dissolved in hydrochloric acid $\left(4.8 \mathrm{~mol} \cdot \mathrm{l}^{-1}\right)$ and $\mathrm{As}^{\mathrm{V}}$ was reduced to $\mathrm{As}^{\mathrm{III}}$ by potassium iodide (Ćelechovská et al. 2005). For hydride generation the solution of $0.3 \% \mathrm{NaBH}_{4}$ in $1 \%$ $\mathrm{NaOH}$ and solution of $1.5 \% \mathrm{HCl}$ were used. Standard reference material DORM-2 (NRC, dogfish muscle) was used to verify the validity of the method. The reproducibility was expressed from five measurements as RSD $4.47 \%$. Detection limit of total arsenic $(3 \sigma)$ and limit of determination $(10 \sigma)$ were $1.1 \mu \mathrm{g}^{\circ} \mathrm{kg}^{-1} \mathrm{and} 4.1 \mu \mathrm{g} \cdot \mathrm{kg}^{-1}$, respectively.

The method of arsenic species assessment comprised of the separation by high performance liquid chromatography and the detection by atomic fluorescence spectrometry with the generation of hydrides (HPLCHG-AFS) by apparatus Millennium Excalibur (PS Analytical, UK).

Arsenic species were extracted from tissue samples by ultra-pure deionized water (Harkabusová et al. 2009). Phosphate buffer of $\mathrm{pH} 6.1$ and concentration of $10 \mathrm{mmol} \cdot \mathrm{l}^{-1}$ was used as a mobile phase. To generate hydrides the solution of $1.4 \% \mathrm{NaBH}_{4}$ in $0.1 \mathrm{~mol} \cdot \mathrm{l}^{-1} \mathrm{NaOH}$ and $6 \mathrm{~mol} \cdot \mathrm{l}^{-1} \mathrm{HCl}$ were used. Conditions for oxidation were ensured by the solution of $1 \% \mathrm{~K}_{2} \mathrm{~S}_{2} \mathrm{O}_{8}$ in $1 \% \mathrm{NaOH}$ and the presence of $\mathrm{UV}$ radiation. The main compound of arsenic detected in fish tissues was arsenobetaine (AsB). Arsenobetaine comes under non-reducible arsenic compounds and arsenite and arsenobetaine eluate together (retention times of both are the same), so we had to carry out two analyses, one with the UV lamp on and the other with the UV lamp off. When photo-oxidation is switched on, arsenobetaine (in the presence of $\mathrm{K}_{2} \mathrm{~S}_{2} \mathrm{O}_{8}$ in $\mathrm{NaOH}$ and ultraviolet radiation) is transformed into the form that reacts with $\mathrm{NaBH}_{4}$ and produces a signal. If the UV lamp is switched off, arsenobetaine and $\mathrm{NaBH}_{4}$ do not react. 
The arsenobetaine concentration is assessed by the signal difference between the analysis with discharge lamp switched on or off. The measurement was performed at a wavelength of $193.7 \mathrm{~nm}$. The accuracy of measurements

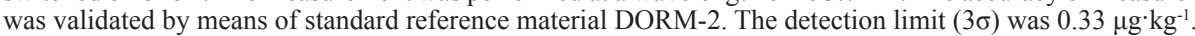

The resulting data were processed by statistical package Unistat 5.1. (Unistat Ltd, GB). Nonparametric KruskalWallis analysis of variance was used for determining the significance of differences of metal concentrations.

\section{Results and Discussion}

Since the analysed fish were kept in tanks with running water from the basin of water processing plant, the ingested feed mixtures were the main source of arsenic.

Mean concentrations of arsenic in feeding mixtures Bio-Optimal $1.1 \mathrm{~mm}$ and $3 \mathrm{~mm}$ were $1.29 \pm 0.73$ and $4.28 \pm 0.11 \mathrm{mg} \cdot \mathrm{kg}^{-1}$, mean contents of arsenic in arsenobetaine were 0.066 \pm 0.004 and $0.96 \pm 0.08 \mathrm{mg} \cdot \mathrm{kg}^{-1}$, which represents about $5 \%$ and $22 \%$ of the total content of arsenic. The mean content of total arsenic in Aqualife feed was $3.56 \pm 0.05 \mathrm{mg} \cdot \mathrm{kg}^{-1}$ and arsenic in arsenobetaine $0.558 \pm 0.018 \mathrm{mg} \cdot \mathrm{kg}^{-1}$, which is $15.7 \%$ of total arsenic. The low portion of arsenobetaine (considering the total amount of arsenic) indicates that the prevailing part of arsenic in feeding mixtures was in the inorganic form.

The relation between weight and length of trout specimens and the period of rearing (Fig. 1) shows that initially the curve was gently rising and the increases in weight and length were small, which correlates with lower water temperature during winter months (Table 1). Significant increase $(P<0.05)$ occurred after the $8^{\text {th }}$ month of rearing (June). With increasing water temperature the trout metabolism was becoming faster and up to the $14^{\text {th }}$ month (December) the weight and length was increasing.

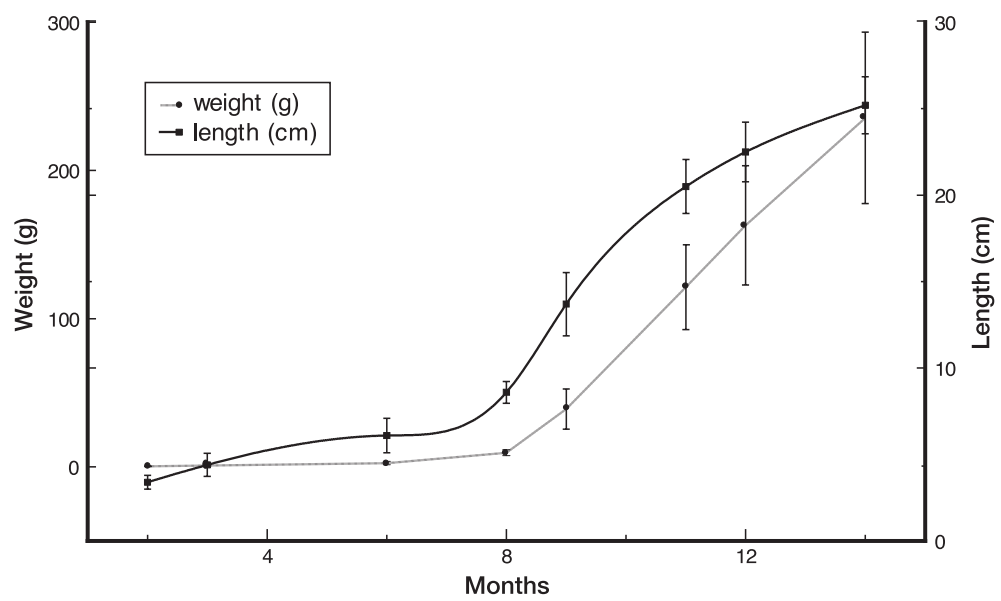

Fig.1. Relation between the weight and length of rainbow trout (Oncorhynchus mykiss) and the period of rearing (months).

We analysed homogenized fish bodies from the $2^{\text {nd }}$ to $9^{\text {th }}$ month of rearing. Concentration of total arsenic in these samples ranged from $0.177 \pm 0.012 \mathrm{mg} \cdot \mathrm{kg}^{-1}$ to $0.741 \pm 0.210$ $\mathrm{mg} \cdot \mathrm{kg}^{-1}$, the content of arsenic in arsenobetain from $0.096 \pm 0.0031 \mathrm{mg} \cdot \mathrm{kg}^{-1}$ to $0.357 \pm$ $0.142 \mathrm{mg} \cdot \mathrm{kg}^{-1}$ (Fig. 2).

The contents of arsenic and arsenobetaine in samples were low; other arsenic species were not detected. The concentration of As significantly increased $(P<0.01)$ to the $3^{\text {rd }}$ month of rearing. From the $6^{\text {th }}$ month, no significant variance was found in the total content of arsenic. The concentration of AsB in homogenized fish during the first months of rearing was very low, a significant increase $(P<0.05)$ occurred in the $6^{\text {th }}$ month. The ratio of 


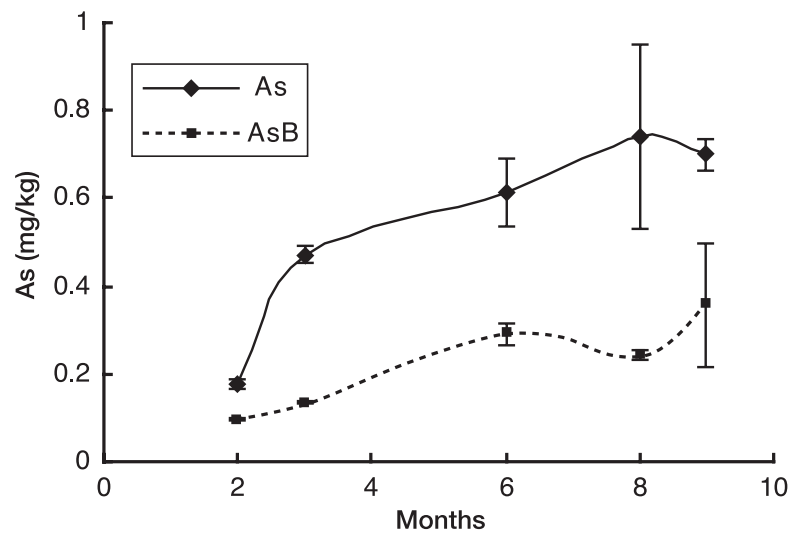

Fig. 2. Dependence of concentrations (mean, SD) of total arsenic (As) and arsenobetaine (AsB) in homogenized bodies of rainbow trout (Oncorhynchus mykiss) on rearing period (months)

concentrations $\mathrm{AsB} / \mathrm{As}$ in homogenized bodies of rainbow trout did not considerably vary. From the $6^{\text {th }}$ to $9^{\text {th }}$ month of rearing they reached $45 \pm 6 \%$.

Total arsenic and arsenobetaine in rainbow trout muscle were determined in fish from the $8^{\text {th }}$ to $14^{\text {th }}$ month of rearing. The value of As ranged from $0.76 \pm 0.22 \mathrm{mg} \cdot \mathrm{kg}^{-1}$ to $1.62 \pm$ $0.19 \mathrm{mg} \cdot \mathrm{kg}^{-1}$. Similar interesting findings were previously published by Berntssen et al. (2010). The AsB concentration in muscle samples ranged from $0.71 \pm 0.06 \mathrm{mg} \cdot \mathrm{kg}^{-1}$ to 1.15 $\pm 0.09 \mathrm{mg} \cdot \mathrm{kg}^{-1}$ (Fig. 3). Amlund et al. (2006) proved that AsB contained in muscle and other organs is not only the product of detoxication but also comes from the feedstuff.

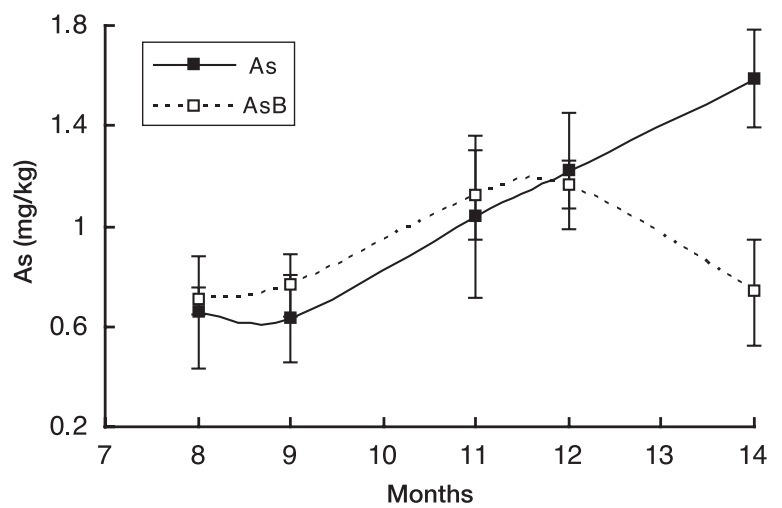

Fig. 3. Dependence of concentrations of total arsenic (As) and arsenobetaine (AsB) in muscle of rainbow trout (Oncorhynchus mykiss) on rearing period (months)

In summer months (from June to October) from the $8^{\text {th }}$ to $12^{\text {th }}$ month of fish rearing, in the period of an intensive metabolism, the values of As and AsB were similar, which means that the entire arsenic was in the form of AsB. In winter months the content of As in muscle increased while AsB content significantly decreased $(P<0.01)$. The content of AsB in liver corresponds to above mentioned conclusions. (Fig. 4).

The concentration of AsB in liver was slowly increasing with a maximum in the $11^{\text {th }}$ month of rearing (October). In the following month it significantly dropped 


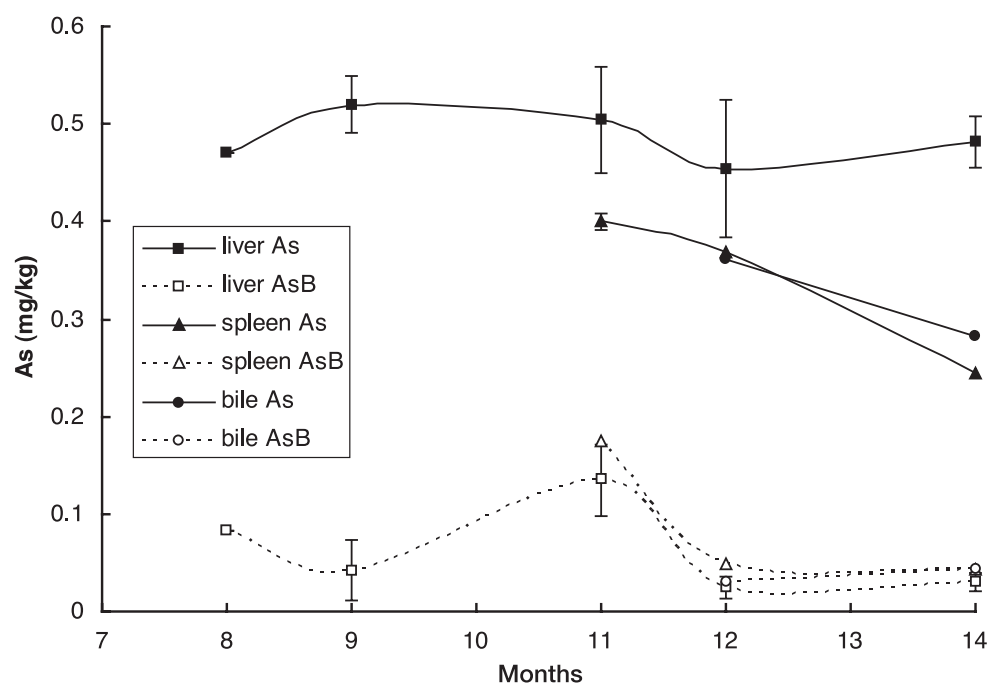

Fig. 4. Dependence of concentration of total arsenic (As) and arsenobetaine (AsB) in the liver, spleen and bile of rainbow trout (Oncorhynchus mykiss) on period of rearing (months)

$(P<0.05)$ and stayed at this level until the end of monitoring. Over the whole monitoring period (in summer and winter months) the values of As in liver did not show any significant difference and the mean concentration was $0.486 \pm 0.036 \mathrm{mg} \cdot \mathrm{kg}^{-1}$. The limited accumulation of As in liver confirms that the organism has a lower capacity to accumulate arsenic. Ventura-Lima et al. (2009) reported similar results during short term monitoring of the impact of various concentrations of inorganic arsenic in carp. The ratio of $\mathrm{AsB} / \mathrm{As}$ in liver reached the maximum at the end of summer $(27 \%)$. The arsenic in liver was transformed into arsenobetaine and this arsenobetaine accumulated in muscle, whereas in winter months arsenic was accumulated in muscle (Fig. 3). The drop in transformation of arsenic into arsenobetaine during winter was caused by lower metabolic rate (Larsen et al. 2001; Svobodová et al. 2002). The study of Chan and Huff (1997) suggests that the methylating capacity changes in dependence on exposure. The periods of the high metabolic rate with arsenic elimination and the tendency to accumulate arsenic in tissues take turns in organism.

From the $11^{\text {th }}$ month of trout age spleen and bile were sampled. Concentration of arsenobetaine in these tissues were in line with those found in liver (Fig. 4). During the entire monitoring the concentration of total arsenic in spleen and bile was consistent; it was lower compared to concentration in liver. But unlike in liver, the concentration of total arsenic decreased $(P<0.05)$ in winter months while retaining the constant content of arsenobetaine. Elimination of arsenobetaine via bile appeared to be insignificant in accordance with findings of Amlund et al. (2006). The highest concentrations of As and AsB in tissues ranked in the order muscle $>$ liver $>$ spleen, bile. The order similar to this one was found in common carp, but with much lower concentration of arsenic (Č elechovská et al. 2007).

In conclusion, this is the first study investigating the effect of the content of arsenic in feedstuff on accumulation of arsenic and arsenobetaine in rainbow trout during the growing period and season. This study proved that most of the arsenic is accumulated in muscle of rainbow trouts. In summer months the raibow trouts have the total arsenic in muscle bonded in the form of non-toxic arsenobetain. 


\section{Kumulace arsenu v pstruhu duhovém (Oncorhynchus mykiss) během vývoje}

Pstruh duhový (Oncorhynchus mykiss) byl sledován po dobu 1 roku, od 2 měsíců do 14 měsíců věku $(\mathrm{n}=120)$. Výzkum probíhal na farmě s tekoucí vodou z vodárenské nádrže Kružberk v letech 2007 a 2008. V prvních měsících života byl analyzován homogenát těl $(n=12)$ pstruhů duhových, od osmého měsíce odchovu bylo odebráno vždy 12 vzorků pstruhů a byla analyzována svalovina, játra, slezina a žluč na obsah celkového arsenu a arsenobetainu. Celkový arsen byl stanovován hydridovou technikou AAS, arsenobetain byl stanovován metodou HPLC s detekcí atomovou fluorescenční spektrometrií. Koncentrace celkového arsenu v homogenátu se statisticky vysoce významně zvyšovala $(P<0,01)$ v prvních měsících života, od 6. měsíce odchovu nebyl zjištěn statisticky významný rozdíl. Arsenobetain $\mathrm{v}$ homogenátu těl pstruhů byl nízký v prvních měsících, od 6 . měsíce se neměnil a dosahoval $46 \pm 6 \%$ celkového arsenu. Nejvyšší koncentrace arsenu a arsenobetainu ve tkáních byly $\mathrm{v}$ pořadí svalovina, játra, slezina a žluč. V letních měsících byl veškerý arsen ve svalovině vázán $\mathrm{v}$ arsenobetainu, $\mathrm{v}$ zimních měsících došlo $\mathrm{k}$ poklesu arsenobetainu až na $50 \%$ celkového arsenu. Koncentrace arsenu v játrech zůstávala po celou dobu konstantní, ale měnilo se zastoupení arsenobetainu. V letních měsících dosahoval maximum $27 \%$, v zimních měsících klesl na $7 \%$ celkového arsenu. Koncentrace arsenu ve slezině a ve žluči se snižovala v zimě, arsenobetain odpovídal hodnotám v játrech.

Studie prokázala vliv malého množství arsenu v krmivu na kumulaci arsenu a arsenobetainu do tkání u pstruhů duhových během vývoje a ročního období.

\section{Acknowledgements}

This research was supported by Ministry of Education, Youth and Physical Training of the Czech Republic, Project MSM No 6215712402 .

\section{References}

Agusa T, Tagaki K, Kubota R, Anan Y, Iwata H, Tanabe S 2008: Specific accumulation of arsenic compounds in green turtles (Chelonia mydas) and hawksbillturtles (Eretmochelys imbriacata) from Ishigaki Island. Japan Environ Pollut 153: 127-136

Amlund H, Ingebrigtsen K, Hylland K, Ruus A, Eriksen DO, Berntssen MHG 2006: Disposition of arsenobetaine in two marine fish species following administration of a single oral dose of [C-14]arsenobetaine. Comp Biochem Phys C 143: 171-178

Berntssen MHG, Julshamn K, Lundebye AK 2010: Chemical contaminants in aquafeeds and Atlantic salmon (Salmo salar) following the use of traditional - versus alternative feed ingredients. Chemosphere 78: 637-646

Čelechovská O, Svobodová Z, Randák T 2005: Arsenic content in tissues of fish from the river Elbe. Acta Vet Brno 74: 419-425

Čelechovská O, Svobodová Z, Žlábek V, Macharáčková B 2007: Distribution of metals in tissues of the common carp (Cyprinus carpio L.). Acta Vet Brno 76: S93-S100

Chan PC, Huff J 1997: Arsenic carcinogenesis in animals and humans. Environ Carcin Ecotox Revs 15: 83-122.

Ciardullo S, Aureli F, Maggi A, Cubadda F 2010: Arsenic speciation in fresh water fish: Focus on extraction and mass balance. Talanta 81: 213-221

Grotti M, Lagomarsino C, Goessler W 2010: Arsenic speciation in marine organism from a Antartic coastal environments. Environ Chem 7: 207-214

Francesconi KA 2010: Arsenic species in seafood: Origin and human implications. Pure Appl Chem 82: 373-381

Harkabusová V, Macharáčková B, Čelechovská O, Vitoulová E, Lavičková A 2009: Determination of arsenic in the rainbow trout muscle and rice samples. Czech J Food Sci 27: S404-S406

Larsen DA, Beckman BR, Dickhoff WW 2001: The effect of low temperature and fasting during the winter on metabolic stores and endocrine physiology (insulin, insulin-likegrowth factor and thyroxine) of coho salmon (Oncorhynchus kisutch). Gen Comp Endocr 123: 308-323

McGeachy SM, Dixon DG 1989: The impact of temperature on the acute toxicity of arsenate and arsenite to rainbow trout (Salmo gairdneri) Ecotoxicol Enviro Saf 17: 86-93

McGeachy SM, Dixon DG 1992. Whole-body arsenic concentrations in rainbow trout during acute exposure to arsenate. Ecotoxicol Environ Saf 24: 301 -308

Pedlar RM, Klaverkamp JF 2002: Accumulation and distribution of dietary arsenic in lake whitefish (Coregonus clupeaformis). Aquat Toxicol 57: 153-166 
Pedlar RM, Ptashynski MD, Evans RE, Klaverkamp JF 2002a: Toxicological effect of dietary arsenic exposure on lake whitefish (Coregonus clupeaformis). Aquat Toxicol 57: 167-189

Pedlar RM, Ptashynski MD, Wautier KG, Evans RE, Baron CL, Klaverkamp JF 2002b: The accumulation, distribution, and toxicological effect of dietary arsenic exposure in lake whitefish (Coregonus clupeaformis) and lake trout (Salvelinus namaycush). Comp Biochem Physiol Part C 131: 73-91

Rankin MG, Dixon DG 1994: Acute and chronic toxicity of waterborne arsenite to rainbow trout (Oncorhynchus mykiss). Can J Fish Aquat Sci 51: 372 -380

Sloth JJ, Julshamn K, Lundebye AK 2005: Total a content arsenic and inorganic arsenic in Norwegian fish feed product. Aquacult Nutr 11: 61-66

Svobodová Z, Čelechovská O, Máchová J, Randák T 2002: Content of arsenic in market-ready rainbow trout (Oncorhychus mykiss). Acta Vet Brno 71: 361-367

Tamaki S, Frankenberger WT Jr 1992: Environmental biochemistry of arsenic. Rev Environ Contam Toxicol 124: 79-110

Ventura-Lima J, Fattirini D, Regoli F, Monserrat JM 2009: Effect of different inorganic arsenic species in Cyprinus carpio (Cyprinidae) tissues after short-time exposure: Bioaccumulation, biotransformation and biological response. Environ Pollut 157: 3479-3484 